\title{
¿Mi casa y mi carro son Activos?
}

\section{Por. Paul Granados}

Máster en Finanzas y Máster en Dirección de Empresas

Catedrático de la Universidad Centroamericana

José Simeón Cañas (UCA)

pgranados@uca.edu.sv

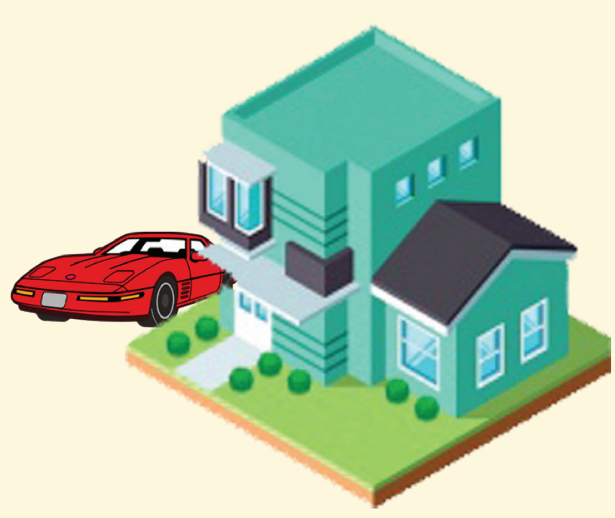

Según definiciones contables un activo es un bien tangible o intangible, propiedad de una empresa o persona natural y un pasivo es una deuda o un compromiso que ha adquirido una empresa, institución o individuo. Sin embargo, estos conceptos muchas veces no son extrapolables a las finanzas personales, según Robert Kiyosaky autor del libro "Padre Rico, Padre Pobre" un activo es una propiedad que pone dinero en tu bolsillo y un pasivo es una propiedad que saca dinero de él.

Si nos remitimos a la definición tradicional de activos, se podría decir que una casa o un carro son "activos" porque cumple con la condición de ser "propiedad", no obstante, en la práctica nos encontramos con el hecho concreto que el carro de uso personal no es una fuente generadora de dinero, más bien es una fuente de egresos de dinero (pago de matrículas, combustibles, reparaciones, etc.). Lo mismo ocurre con las casas para usos habitacionales, son bienes que tiene asociados egresos como: pago de hipoteca, seguros, servicios básicos, mantenimientos, entre otros, por dicha razón y atendiendo al concepto moderno de activos y pasivos en las finanzas personales, las casas, carros y cosas que se utilizan para el uso particular NO SON ACTIVOS.

Con esto no te quiero decir que comprar una casa es algo malo, lo verdaderamente importante, más allá de comprar o no un bien de capital, es comprender el concepto real de activo y pasivo en las finanzas personales, por ejemplo: Si se adquiere una casa con el propósito de arrendarla y así generar un flujo de dinero mensual mayor a los gastos asociados al bien, entonces puedes decir con certeza que tienes un "activo", ahora bien, si adquieres la casa para propósitos de vivienda familiar, el bien sólo generarán flujos de efectivo de salida en tu bolsillo por lo tanto tienes un "pasivo".

De modo que, una casa o un carro puede ser un activo o un pasivo, dependiendo de las palabras más importante en los negocios: ¡EL FLUJO DE EFECTIVO GENERADO!

En conclusión, si el recurso que posees deja un flujo de dinero positivo en tu bolsillo entonces es un activo, por el contrario, si el bien que posees retira dinero de tu bolsillo es un pasivo.

Antes de finalizar me gustaría hacerte la siguiente pregunta: Si te jubilas hoy, ¿qué bienes te seguirán generado flujos de efectivo a lo largo de tu vida?. Si tienes una respuesta a esta pregunta entonces tienes activos reales, de lo contrario es un buen momento para empezar a trabajar en la construcción de estos.

¡No llames activos a lo que realmente son pasivos!, recuerda que el conocimiento es poder y mientras más te eduques financieramente, más cerca estarás de esa anhelada libertad financiera que buscas. 